\title{
HBsAg, Anti-HBs, Anti-HCV and HIV Seroprevalence in Hemodialysis Patients in Elazığ Province
}

\section{Elazığ Ilinde Hemodiyaliz Hastalarında HBsAg, Anti-HBs, Anti-HCV ve HIV Seroprevalansı}

\author{
๑ Gülden ESER KARLIDAĞ1' • Mehmet KÜÇÜKSU2, ๑ Mustafa DEMIR33 \\ 1 University of Health Sciences, Elazığ Training and Research Hospital, Clinic of Infectious Diseases and Clinical Microbiology, Elazı̆̆, Turkey \\ 2University of Health Sciences, Elazığ Training and Research Hospital, Clinic of Nephrology, Elazığ, Turkey \\ ${ }^{3}$ Firat University Faculty of Medicine, Department of Nephrology, Elazığ, Turkey
}

\begin{abstract}
Objectives: This study aimed to determine the rates of hepatitis $B$ surface antigen ( $\mathrm{HBsAg})$, anti-HBs, anti-hepatitis $\mathrm{C}$ virus $(\mathrm{HCV})$ and human immunodeficiency virus (HIV) seropositivity in hemodialysis patients in Elazığ province.

Materials and Methods: All patients receiving hemodialysis in Elazığ province were included in the study. Patients with HBsAg, anti-HBs, anti-HCV and HIV seropositivity were retrospectively evaluated using data between January 1, 2017 and December 12, 2017. Serological HBsAg, anti-HBs, anti-HCV and HIV values were tested. Patients' data regarding age, sex and dialysis duration were recorded.

Results: A total of 434 patients were included in the study. A hundred and sixty seven patients (38.5\%) were female, and 267 $(61.5 \%)$ were male. The mean age of the patients was 59.04 (range: 12-87) years. HBsAg, anti-HBs and anti-HCV positivity was detected in a total of $25(5.8 \%) 341(78.6 \%)$ and of $5(1.2 \%)$ patients, respectively. HIV positivity was not found in any of the patients. When the relationship of seropositivity with dialysis durations and age groups was evaluated, no statistically significant difference was detected between the subgroups for $\mathrm{HBsAg}$, anti-HBs and anti-HCV positivity rates.

Conclusion: The low rate detected for anti-HCV positivity in this study was related with the low prevalence of HCV in our province, decrease in the need for transfusion as a result of erythropoietin use, and strict and monitored application of infection control measures. Keywords: Hemodialysis, hepatitis B, hepatitis C, human immunodeficiency virus, seroprevalence
\end{abstract}

öz

Amaç: Bu çalışmanın amacı, Elazığ ilindeki hemodiyaliz hastalarında hepatit B yüzey antijeni ( $\mathrm{HBsAg})$, anti-HBs, anti-hepatit $\mathrm{C}$ virüsü $(\mathrm{HCV})$ ve insan immün yetmezlik virüsü (HIV) seropozitiflik oranlarını belirlemektir.

Gereç ve Yöntemler: Elazığ'da hemodiyaliz alan tüm hastalar, bu çalışmaya dahil edildi. Hastaların HBsAg, anti-HBs, anti-HCV ve HIV seropozitiflik durumları 1 Ocak - 12 Aralık 2017 tarihleri arasındaki veriler kullanılarak retrospektif olarak incelendi. HBsAg, anti-HBs, anti-HCV ve HIV serolojik değerleri test edildi. Hastaların yaş, cinsiyet ve diyalize girme süreleri kaydedildi.

Bulgular: Çalışmaya toplam 434 hasta alındı. Bunların 167'si $(\% 38,5)$ kadın, 267'si $(\% 61,5)$ erkek idi. Hastaların yaşları 12 ile 87 arasında (ortalaması 59,04) idi. HBsAg pozitifliği toplam $25(\% 5,8)$ hastada saptandı. Bu hastaların 20'si $(\% 4,6)$ erkek ve 5'i $(\% 1,2)$ kadın idi. Anti-HBs pozitifliği toplam $341(\% 78,6)$ hastada saptandı. Anti-HCV, toplam $5(\% 1,2)$ hastada pozitif saptandı. HIV poztitifliği hiçbir hastada saptanmadı. Diyalize girme süreleri ve yaş gruplarıyla ilgili seropozitiflik ilişkisi değerlendiğinde HBsAg, anti-HBs, anti-HCV pozitiflik oranında gruplar arasında anlamlı istatistiksel farklılık saptanmadı.

Sonuç: Bu çalışmada anti-HCV pozitifliği için tespit edilen düşük oran, ilimizdeki düşük HCV prevalansına, eritropoetin kullanımı sonucu transfüzyon ihtiyacının azalmasına ve enfeksiyon kontrol önlemlerinin sıkı ve takipli uygulanması ile ilişkili olduğunu düşünmekteyiz.

Anahtar Kelimeler: Hemodiyaliz, hepatit B, hepatit C, insan immün yetmezlik virüsü, seroprevalans

Eser Karlıdağ G, Küçükssu M, Demir M. HBsAg, Anti-HBs, Anti-HCV and HIV Seroprevalence in Hemodialysis Patients in Elazığ Province. Viral Hepat J. 2018;24:53-56. 


\section{Introduction}

Today, viral hepatitis is still an important health issue. The reasons increasing the risk of infection include more frequent blood transfusion in patients receiving hemodialysis (HD) with the diagnosis of chronic kidney disease compared to the general population, the necessity of vascular intervention with $\mathrm{HD}_{\text {, }}$ advanced age, large number of patients receiving HD in the same place, increased sensitivity in patients due to weakened immune system, frequent hospitalization and surgical intervention. The prevalence of hepatitis B virus (HBV) and hepatitis C virus ( $\mathrm{HCV}$ ) infection is known to be higher in special populations such as HD patients compared to the general population (1). Infection rates are higher in HD patients compared to continuous ambulatory peritoneal dialysis or home HD patients (2). Recent studies have reported that in our country, hepatitis B surface antigen ( $\mathrm{HbsAg}$ positivity rate was $1-3 \%$ and anti-HCV positivity rate was around $1 \%$ in healthy individuals $(1,3)$. It has been reported that HBsAg was found to be positive in $5.7 \%$ of HD patients, anti-HCV-positivity in $6.6 \%$, and both HBsAg and anti-HCV positivity was found in small number of patients (1.1\%) (4). This study mainly aimed to determine the rates of HBsAg, anti-HBs, anti-HCV and human immunodeficiency virus (HIV) seropositivity in HD patients in Elazığ province. Furthermore, with these data (as they are the initial data of this province), this study contributes to epidemiological data of our country and future studies aiming to determine the efficacy of infection control measures taken for HD patients.

\section{Materials and Methods}

All HD patients receiving treatment in four public hospitals and three private dialysis centers in Elazığ province were included in the study. Approval for the study was taken from Firat University, Ethics Committee (decision no: 08, date: 01.02.2018). The patients statuses of HBsAg, anti-HBs, anti-HCV and HIV seropositivity were retrospectively examined using data between January 1, 2017 and December 12, 2017. Patients' data regarding age, sex and dialysis duration were recorded individually. The patients were evaluated in five subgroups by dialysis duration as 0-12 months, 13-36 months, 37-72 months, 73-120 months, 121 months and over; and in eight subgroups by age as 10-19 years, 20-29 years, 30-39 years, 40-49 years, 50-59 years, 60-69 years, $70-79$ years, and 81 years and over.

\section{Statistical Analysis}

Serological HBsAg, anti-HBs, anti-HCV and HIV values were studied using Centaur XP Immunoassay system (Siemens,
USA). HCV-RNA levels were measured by real-time polymerase chain reaction using Rotor-Gene $\mathrm{Q}$ instruments (Qiagen, Hilden, Germany). Data were assessed using SPSS package software v. 22.0. Pearson's chi-square test was used for the intergroup difference, and a $\mathrm{p}$ value of less than 0.05 was considered statistically significant.

\section{Results}

A total of 434 dialysis patients were included in the study. A hundred sixty seven patients (38.5\%) were female, and 267 $(61.5 \%)$ were male. The mean age of the patients was 59.04 years (range: 12-87), and the dialysis duration varied between 1 month and 240 months. HBsAg positivity was detected in a total of 25 $(5.8 \%)$ patients. Twenty (4.6\%) were male, and $5(1.2 \%)$ were female. Anti-HBs positivity was detected in a total of $341(78.6 \%)$ patients. When evaluated by sex, anti-HBs was positive in 145 (87\%) females and 267 (73.4\%) males. Anti-HCV was detected to be positive in a total of 5 (1.2\%) patients ( 2 females and 3 males). All these patients had received antiviral therapy. HCV-RNA values were negative at 6 month after the completion of treatment. Their follow-up was ongoing. HIV-positivity was not detected in any of the study participants. Coexistence of HBsAg- and antiHCV-positivity was not present in any of the study participants. When the relationship of seropositivity with dialysis durations and age groups was evaluated, no statistically significant difference was detected between the subgroups for HBsAg, anti-HBs and anti-HCV positivity rates ( $\mathrm{p} \geq 0.05)$. HBsAg, anti-HBs and anti-HCV distribution by dialysis duration and age is shown in Tables 1 and 2 .

\section{Discussion}

Hepatitis B and hepatitis C infection is still an important cause of morbidity and mortality in the world, and also one of the global public health issues. It has been reported that there were 248 million HBV carriers in the world, and annually, 600.000 individuals die from cirrhosis and hepatocellular carcinoma due to HBV infection. According to the World Health Organization data, it has been reported that approximately 450 million new cases occur each year and approximately $25 \%$ of these cases become chronic. These data suggest that this course will continue (5). Our country is in a region of moderate endemicity (2-7\%) for HBV infection. According to the epidemiological data in our country, 3.5 million individuals are infected with HBV. HBV seroprevalence varies by region. In studies performed between 2008 and 2011 with the cooperation of the Association of Viral Hepatitis Control

Table 1. Hepatitis B surface antigen, anti-hepatitis B surface and anti-hepatitis C virus distribution by dialysis duration

\begin{tabular}{|c|c|c|c|c|c|c|c|}
\hline & & \multicolumn{5}{|c|}{ Dialysis duration } & \multirow[b]{2}{*}{ Total } \\
\hline & & $0-12$ months & $13-36$ months & 37-72 months & $73-120$ months & $121-\ldots$ months & \\
\hline HBsAg-positive & $\mathrm{n}$ & 3 & 5 & 6 & 8 & 3 & 25 \\
\hline \multirow[t]{2}{*}{ Anti-HBs-positive } & $\mathrm{n}$ & 27 & 106 & 86 & 65 & 57 & 341 \\
\hline & $\%$ & $6.2 \%$ & $24.4 \%$ & $19.8 \%$ & $15.0 \%$ & $13.1 \%$ & $78.6 \%$ \\
\hline Anti-HCV-positive & $\%$ & $0.0 \%$ & $0.0 \%$ & $0.5 \%$ & $0.5 \%$ & $0.2 \%$ & $1.2 \%$ \\
\hline
\end{tabular}




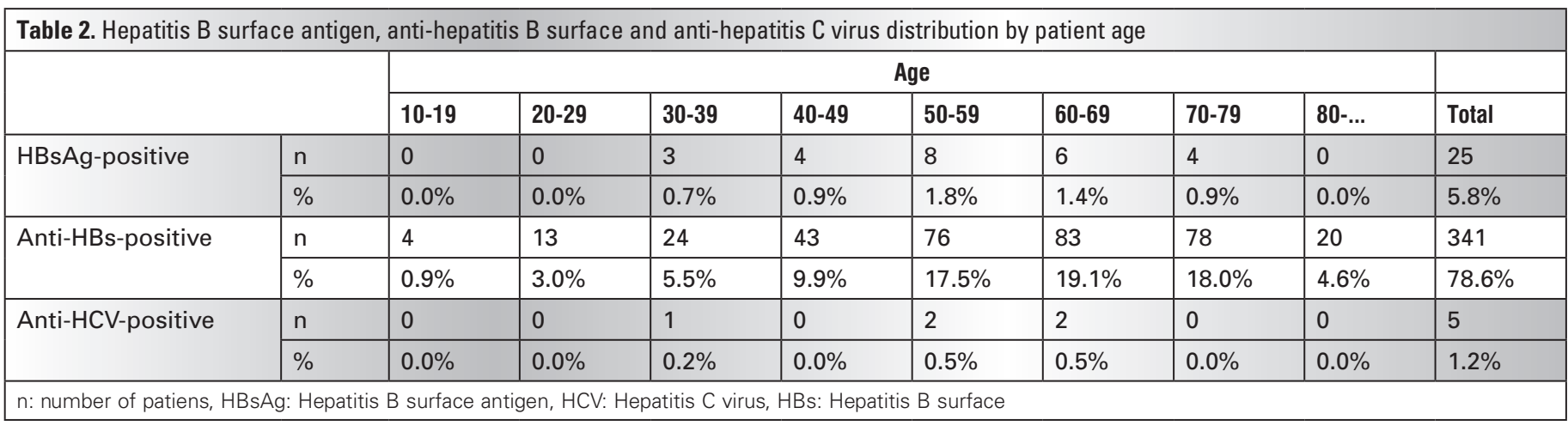

and Turkish Association for the Study of Liver (TASL), HBsAg prevalence was detected to be $2.4 \%, 1.9 \%, 3 \%$ and $2.7 \%$, respectively by year. The highest prevalence was detected in the Southeastern Anatolia region with the rate of $4.1 \%$ and the lowest rate in Aegean region with $1.4 \%$ (1). More than $75 \%$ of HBV-infected patients in the general population around the world live Asia-Pacific countries. In a study involving Asia-Pacific countries, Johnson et al. (6) have reported an HBV seropositivity rate of $1.3-14.6 \%$. In their multi-center, cross-sectional study involving seven countries, Burdick et al. (7) have detected a mean of 3\% (0-6.6\%) HBV seroprevalence in HD patients. In this study, they have reported that the HBV prevalence was $0-5 \%$ in $75 \%$ of dialysis units. According to the data of the Turkish Association of Nephrology in 2015, the prevalence of HBsAg-positivity has been reported to be $5.7 \%$ in chronic HD patients (1). Kaplan et al. (8) evaluated 3023 HD patients in Sivas province between 2002 and 2011, and detected a HBsAg seroprevalence rate of $3.5 \%$. In studies performed in HD patients in various regions of our country, HBsAg-positivity was found to be $5.5 \%$ in Rize by Çiçek et al. (9), 6\% in Istanbul by Alp (10), 3.6\% in Hatay by Evirgen et al. (11), and $4.8 \%$ in Çanakkale by Arabacı and Olcaday (12). Due to immunosuppression in HD patients, the rate of achieving protective antibody response $(10 \mathrm{mlU} / \mathrm{mL})$ is low despite highdose vaccination $(40 \mathrm{~g})$ (13). It has been reported that while response to 3 doses of vaccine in individuals with normal immune response was $90-95 \%$, the mean rate of response to vaccination in HD patients was 64\% (34-88\%) (14). In some recent studies in our country, the vaccination response rate has been reported to be between $72.2 \%$ and $80 \%(9,11,12)$. In our study, we detected $5.5 \%$ HBsAg-positivity and $78.6 \%$ anti-HBs-positivity in HD patients. Our rates are comparable with the data in recent studies in our country. There are studies reporting the relationship of HBsAg-positivity with HD duration differently. While Franco et al. (15), from Italy, have demonstrated a relationship between HbsAg-positivity and HD duration, Balat et al. (16), from our country, detected no significant relationship. Our study did not find a statistically significant relationship between HD duration and HBsAg- and anti-HBs-positivity either. The mean prevalence of $\mathrm{HCV}$ infection is $2-3 \%$ in the world. Risk factors for HCV infection vary by region and population (17). In a country-wide study performed in Turkey by the TASL, the rate of anti-HCV positivity was found to be $0.95 \%$ in the general population (18). When global studies in HD patients were reviewed, a decrease was observed in anti-HCV positivity over time but an increase was also detected in some countries. HCV infection is especially important in dialysis patients because the prevalence is much higher than in the general population due to nosocomial transmission $(9,19)$. In a meta-analysis in HD patients, being HCV carrier was found to increase the risk of mortality by 1.57 -fold (20). Anti-HCV positivity rate varies by geographical region. In a multi-center study performed by Jadoul et al. (21) in Europe, it has been reported that anti-HCV prevalence decreased from $13.5 \%$ in 1991 to $6.8 \%$ in 2000 , in Belgium, from $42 \%$ to $30 \%$ in France, from $16 \%$ to $9 \%$ in Switzerland, $28 \%$ to $16 \%$ in Italy, from $7 \%$ to $3 \%$ in the UK and from $26 \%$ to $15 \%$ in Hungary, and increased from $5 \%$ to $12 \%$ in Spain and from $42 \%$ to $44 \%$ in Poland. The authors have associated these decreases with the decrease in blood transfusion rates, thanks to erythropoietin use, and the increase in the sensitivity of anti-HCV tests. In our study, anti-HCV was found to be positive in 5 of 434 patients (1.2\%). According to the data of the Turkish Association of Nephrology in 2015, the prevalence of anti-HCV-positivity in chronic HD patients has been reported to be $6.6 \%$ (1). In studies in our country, anti-HCV positivity was detected to be $28 \%$ by Alp (10), $4.1 \%$ by Temiz et al. (22), $9.5 \%$ by Evirgen et al. (11), 10\% by Bozkurt et al. (23), 16\% by Çiçek et al. (9), and $10.6 \%$ by Arabacı and Olcaday (12).

\section{Conclusion}

In our study, the rate of anti-HCV positivity was detected to be $1.2 \%$. This value was lower than in the data published in recent years. We think that the low rate of anti-HCV positivity and the low prevalence of HCV infection in HD patients in our study are related with the low prevalence of HCV in our province, decrease in the need for transfusion as a result of erythropoietin use, and strict application of infection control measures. There was no anti-HIVpositive patient among HD patients in our study. While anti-HIV seroprevalence varies by geographical region, this result can be explained by the very low anti-HIV seroprevalence in our province. Our study involved all HD patients in the province. Our rates of $\mathrm{HBsAg}$ and anti-HBs in this study are comparable with the overall rates in the country. We think that the low rate detected for anti$\mathrm{HCV}$ positivity in this study is related with the low prevalence of $\mathrm{HCV}$ in our province, decrease in the need for transfusion as a result of erythropoietin use, and application of infection control measures. Together with the hepatitis $\mathrm{C}$ treatment options providing cure in recent years, we think that the rate of $\mathrm{HCV}$ infection will also decrease in the country. 


\section{Ethics}

Ethics Committee Approval: Approval for the study was taken from Firat University Ethics Committee (decision no: 08, date: 01.02.2018).

Informed Consent: Informed consent is not required due to retrospective design of the study.

Peer-review: Externally peer-reviewed.

\section{Authorship Contributions}

Surgical and Medical Practices: G.E.K., M.K., M.D., Concept: G.E.K., Design: G.E.K., M.K., Data Collection or Processing: G.E.K., M.K., M.D., Analysis or Interpretation: G.E.K., M.D., Literature Search: G.E.K., M.K., M.D., Writing: G.E.K.

Conflict of Interest: No conflict of interest was declared by the authors.

Financial Disclosure: The authors declared that this study received no financial support.

\section{References}

1. Tosun S. Türkiye'de viral hepatit B epidemiyolojisi yayınlarının meta analizi. Viral Hepatit 2013. Ed: Tabak F, Tosun S. Viral Hepatitle Şavaşım Derneği. Istanbul Tıp Kitapevi, 1. Baskı, Istanbul. 2013;25-80.

2. Nicolardi E, Grieco A, Rapaccini GL, Pompili M. Natural history, diagnosis and treatment of chronic hepatitis $B$ and $C$ in hemodialysis patients. G Ital Nefrol. 2010;27:262-273.

3. Mıstık R. Hepatit C virüs enfeksiyonunun epidemiyolojisi. Viral Hepatit 2013. Ed: Tabak F, Tosun S. Viral Hepatitle Savaşım Derneği. Istanbul Tıp Kitapevi 1. Baskı, Istanbul. 2013;81-112.

4. Seyahi N, Ateş K, Süleymanlar G. Türkiye'de Renal Replasman Tedavilerinin Güncel Durumu: Türk Nefroloji Derneği Kayıt Sistemi 2015 Yılı Özet Raporu. Turk Neph Dial Transpl. 2017;26:154-160.

5. Teo EK, Lok ASF. Epidemiology, transmission, and prevention of hepatitis B virus infection. Eds: Kaplan SL, Esteban R. Literature review current through: Feb 2018. I This topic last updated: Oct 31, 2016.

6. Johnson DW, Dent H, Yao Q, Tranaeus A, Huang CC, Han DS, Jha $V$, Wang T, Kawaguchi Y, Qian J. Frequencies of hepatitis B and C infections among haemodialysis and peritoneal dialysis patients in Asia-Pacific countries: analysis of registry data. Nephrol Dial Transplant. 2009;24:1598-1603

7. Burdick RA, Bragg-Gresham JL, Woods JD, Hedderwick SA, Kurokawa K, Combe C, Saito A, LaBrecque J, Port FK, Young EW. Patterns of hepatitis B prevalence and seroconversion in hemodialysis units from three continents: the DOPPS. Kidney Int. 2003;63:2222-2229.

8. Kaplan Ö, Bakıcı MZ, Celik C, Kayataş M, Candan F. Cumhuriyet Üniversitesi Araştırma ve Uygulama Hastanesi hemodiyaliz ünitesi hastalarının HBsAg ve Anti HCV seropozitiflikleri. Viral Hepat J. 2013;19:126-130.
9. Çiçek AÇ, Şahin OZ, Topaloğlu MK, Taşkaya Kazancı AA, Yenilmez IH, Şahin K, Ulusan Gündoğdu DZ. Rize Illinde Hemodiyaliz Hastalarında HBsAg, Anti-HBs ve Anti-HCV Seroprevalansı. Viral Hepat J. 2013;19:15-18.

10. Alp I. Haydarpaşa Numune Eğitim ve Araştırma Hastanesi hemodiyaliz hastalarında Hepatit B, C ve D seroprevelansı. (Uzmanlık Tezi) Istanbul, 2009.

11. Evirgen Ö, Önlen Y, Motor VK, Mahsereci E, Inci M, Şahin Ş. Hatay Ili Hemodiyaliz Hastalarında HBV, HCV Seroprevalansı ve Hepatit B Aşılaması ile oluşan Antikor Cevabının Değerlendirilmesi. Viral Hepat J. 2010;16:57-63.

12. Arabacı F, Olcaday M. Çanakkale ilinde farklı diyaliz merkezlerinde tedavi gören hastalarda Hepatit B, C seroprevalansı ve hepatit kronikleşme oranları. Turk Hij Den Biyol Derg. 2009;66:161-167.

13. Palmović $D$, Crnjaković-Palmović J. Vaccination against hepatitis $B$ : results of the analysis of 2000 population members in Croatia. Eur J Epidemiol. 1994;10:541-547.

14. [No authors listed]. Recommendations for preventing transmission of infections among chronic hemodialysis patients. MMWR Recomm Rep. 2001;50:1-43.

15. Franco E, Olivadese A, Valeri M, Albertoni F, Petrosillo N. Control of hepatitis B virus infection in dialysis units in Latium, Italy. Nephron. 1992;61:329-330.

16. Balat A, Durmaz B, Tergut M, Otlu B. Kronik hemodiyaliz hastaları ile bu ünitelerde çalışanlarda hepatit $B, C, D$ ve $E$ serolojik göstergeleri. Türk Nefroloji Diyaliz ve Transplantasyon Derg. 1998;2:92-96.

17. Alter MJ. HCV routes of transmission: what goes around comes around. Semin Liver Dis. 2011;31:340-346.

18. Tözün N, Özdoğan OC, Çakaloğlu Y, Idilman R, Karasu Z, Akarca US, ve ark. A Nationwide prevalence study and risk factors for hepatitis A, B, C and D infections in Turkey. Hepatology. 2010;52(Suppl 1):697.

19. Khokhar N, Alam AY, Naz F, Mahmud SN. Risk factors for hepatitis $C$ virus infection in patients on long-term hemodialysis. J Coll Physicians Surg Pak. 2005;15:326-328.

20. Fabrizi F, Martin P, Dixit V, Bunnapradist S, Dulai G. Meta-analysis: Effect of hepatitis $C$ virus infection on mortality in dialysis. Aliment Pharmacol Ther. 2004;20:1271-1277.

21. Jadoul M, Poignet JL, Geddes C, Locatelli F, Medin C, Krajewska M, Barril G, Scheuermann E, Sonkodi S, Goubau P; HCV Collaborative Group. The changing epidemiology of hepatitis $C$ virus $(\mathrm{HCV})$ infection in haemodialysis: European multicentre study. Nephrol Dial Transplant. 2004;19:904-909.

22. Temiz H, Kaya Ş, Berekatoğlu N, Temiz S, Danış R. Hemodiyaliz Hastalarında HBV, HCV ve HIV Seroprevalansı ve Hepatit B aşılaması ile oluşan antikor cevabının değerlendirilmesi. Viral Hepat J. 2013;19:140-143

23. Bozkurt I, Aygen B, Yıldız O, Gökahmetoğlu S. Bölgemizdeki hemodiyaliz hastalarında Hepatit C Virusu infeksiyonunun sıklığı ve epidemiyolojik özellikleri. Klimik Dergisi. 2011;24:167-72. 